\title{
Utilization of Fermented Yeast Rice by the Fungus Monascus ruber AUMC 4066 as Food Coloring Agents
}

\section{Darwish $\mathbf{A Z}^{1 *}$, Darwish $\mathbf{S M}^{2}$ and Ismail MA ${ }^{3}$}

${ }^{1}$ Department of Dairy Science, Faculty of Agriculture, Assiut University, Egypt

${ }^{2}$ Department of Food Science and Technology, Faculty of Agriculture, Assiut University, Egypt

${ }^{3}$ Department of Botany and Microbiology, Faculty of Science, Assiut University, Egypt

\begin{abstract}
The red fermented rice has higher nutritive value and the function of building up body. The red rice contains abundant protein, fats, vitamins, trace elements and coarse fiber. Red yeast rice fermented by Monascus ruber 4066 was used for the study. Yogurts with Streptococcus thermophilus and Bifidobacterium bifidum were prepared using cow's milk supplemented with red yeast rice flour (RYRF) at $1 \%, 2 \%, 3 \%$ (wt/wt) and stored at $5^{\circ} \mathrm{C}$ to 14 days. All preparations of RYRF yogurts showed higher titratable acidity, viscosity, water holding capacity (WHC), hardness, adhesiveness and cohesiveness compared to that of plain yogurts throughout the storage period. The count of $B$. bifidum in RYRF yogurts $\left(>7 \log \mathrm{cfu}\right.$. $\left.\mathrm{g}^{-1}\right)$ was more than that of plain yogurts $(>6$ $\left.\log \mathrm{cfu} . \mathrm{g}^{-1}\right)$ at the end of storage period, probably due to prebiotic effect of RYRF. There were significant differences among the yogurt samples in relation to their organoleptic properties. The current results recommend addition of $3 \% \mathrm{RYRF}$ to yoghurt that enhanced physicochemical, organoleptic and textural properties and the viability of $B$. bifidum in bio-yoghurt as functional food.
\end{abstract}

Keywords: Monascus ruber; Yoghurt; S. thermophilus; B. bifidum; Functional food; Red yeast rice

\section{Introduction}

Yoghurt is one of the most popular fermented milk products worldwide [1] and is becoming more and more popular in Egypt. Bifidobacteria has been associated with health-promoting effects; there has been an increasing in incorporating this microbial group into dairy and dairy foods or supplementing dairy foods. The ultimate intent of this strategy is to provide the gastrointestinal tract of humans with viable populations of bifidobacteria. Food coloring is very important for commercial food production especially children food. Therefore, there is a need to other alternative sources of natural food colorants like microorganisms, some pigments have been produced from Monascus [2]. Production of pigments from Monascus depends on the kind of metabolites, yield, colour degree, stability, and safety, as well as on the strains, substrates and cultivation conditions [3-6]. Monascus fermented rice has been used as a natural food colorant, food preservative and as functional food because of the monacolin $\mathrm{K}$ (antihypercholesterolemic agents), $\gamma$-aminobutyric acid (GABA) (hypotensive agent), and dimerumic acid (antioxidant) found [7]. Bioactivity metabolites for Monascus spp. included aroma and flavor compound, antibacterial, anticancer, anti-cardiovascular disease, anticholesterols and antioxidant, human health supporting health care and immune enhancer metabolites [5,8]. Traditionally fermented red yeast rice proved to contain many active constituents such as compounds resembling statins, unsaturated fatty acid, sterols and B-complex vitamins [9]. Chen et al. [10] revealed that ethanolic extracts of two $M$. ruber strains cultivated on different media and analyzed by TLC and GC/MS were free of citrinin because the gene which responsible for citrinin biosynthesis has not been found in $M$. ruber. Therefore, the red pigments of $M$. ruber strains can be safe for biotechnological applications [11]. Colored yoghurt using the red pigment from Monascus ruber may have health-promoting constituents. This study investigated the effect of functional properties of red yeast rice Monascus ruber at different concentration of $1 \%$, $2 \%$ and $3 \%(\mathrm{w} / \mathrm{w})$ on the organoleptic, physicochemical and textural properties, and B. bifidum viability in yogurt samples during the storage period 14 days at $5^{\circ} \mathrm{C}$.

\section{Materials and Methods}

\section{Monascus strains}

A strain of M. ruber AUMC 4066 (CBS 109.07) kindly obtained from Assiut University Mycological Centre Collection, Assiut, Egypt, was maintained on rice agar slant containing (in $\mathrm{g} / \mathrm{L}$ ): rice powder 50 , $\mathrm{KH}_{2} \mathrm{PO}_{4} 2.5, \mathrm{NaNO}_{3} 3 \mathrm{MgSO}_{4} .7 \mathrm{H}_{2} \mathrm{O} .0 .5$ and distilled water $1 \mathrm{~L}, \mathrm{pH}$ to 6 $[4,11]$, the medium was dispensed in tubes and was then autoclaved at $121^{\circ} \mathrm{C}$ for $15 \mathrm{~min}$. The fungus was incubated at $26^{\circ} \mathrm{C}$ for 10 days under static conditions, to the fully speculated agar slants, $10 \mathrm{ml}$ of sterile distilled water were added and the spores were scraped under aseptic conditions. The obtained spore suspension was used as inoculum.

\section{Fermentation media and cultivation}

Commercial rice from those marketed at Assiut was used. The fungus was grown on natural rice medium. Aliquots of $200 \mathrm{gm}$ rice moistened with $20 \%$ water in $500 \mathrm{ml}$ Erlenmeyer flasks were autoclaved. Flask was inoculated with $10 \mathrm{ml}$ spore suspension and incubated at $26^{\circ} \mathrm{C}$ for 10 days. Flasks containing cultures were put at $45^{\circ} \mathrm{C}$ till completes drying. The dried cultures were ground and used as food coloring agent.

\section{Production of probiotic yogurts}

Set and stirred probiotic yogurts were produced using a standard yogurt manufacturing procedures. Standardized milk ( $4 \%$ fat and $12 \%$ SNF) was homogenized at $60^{\circ} \mathrm{C}$ and then pasteurized at $95^{\circ} \mathrm{C}$ for $15 \mathrm{~min}$.

*Corresponding author: Darwish AZ, Department of Dairy Science, Faculty of Agriculture, Assiut University, Egypt, Tel: +20-1112325374, Fax: +20-88-233-1384; E-mail: zahraadarwish@yahoo.com

Received December 09, 2016; Accepted December 28, 2016; Published January 04, 2017

Citation: Darwish AZ, Darwish SM, Ismail MA (2017) Utilization of Fermented Yeast Rice by the Fungus Monascus ruber AUMC 4066 as Food Coloring Agents. J Food Process Technol 8: 645. doi: 10.4172/2157-7110.1000645

Copyright: () 2017 Darwish AZ, et al. This is an open-access article distributed under the terms of the Creative Commons Attribution License, which permits unrestricted use, distribution, and reproduction in any medium, provided the original author and source are credited. 
The milk was then cooled at $43^{\circ} \mathrm{C}$ and aseptically inoculated with $0.01 \%$ (w/w) of each strain of L. acidophilus and B. bifidum. Additionally, an equal mixture of the two strains with a ratio of $1: 1(0.01 \% \mathrm{w} / \mathrm{w})$ was added to the milk. Bar-berry extract in different concentration of $4 \%$ and $5 \%(\mathrm{w} / \mathrm{w})$ was further added to the sterile containers to produce set yogurt and then it was incubated at $37^{\circ} \mathrm{C}$ for $18 \mathrm{~h}$. Besides, after the preliminary incubation, barberry extracts in concentration of $4 \%$ and $5 \%(\mathrm{w} / \mathrm{w})$ were added to obtain stirred yogurt. All the cultured milk groups were then left for a final fermentation at $43^{\circ} \mathrm{C}$. The fermentation was terminated when the acidity level reached a $\mathrm{pH}$ value of 4.7 . Next, yogurt samples were cooled to $5^{\circ} \mathrm{C}$ and held at this temperature for one day. All the experimental samples were subjected to microbiological analysis during the $21^{\text {st }}$ day of storage period.

\section{Red yeast rice}

Red yeast rice fermented by strain of M. ruber, AUMC 4066 from Assiut University Mycological Centre, Assiut, Egypt. Preparation of inoculum Monascus ruber strains were grown on rice slants at $26^{\circ} \mathrm{C}$ under static conditions.

\section{Production of RYRF yoghurt}

Yogurts were produced using a standard yogurt manufacturing procedures [12]. Red yeast rice flour at different concentration of $1 \%$, $2 \%$ and $3 \%(\mathrm{w} / \mathrm{w})$ was added to the sterile containers in cow milk $(3 \%$ fat, $11.5 \% \mathrm{TS}, 0.17 \% \mathrm{TA}$ and $6.6 \mathrm{pH}$ ) and pasteurized in a water bath at $85^{\circ} \mathrm{C}$ for $30 \mathrm{~min}$. The milk was then cooled at $43^{\circ} \mathrm{C}$ and aseptically inoculated with yogurt starter culture Streptococcus thermophilus and B. bifidum at a ratio of $1: 1$ and then it was incubated at $37^{\circ} \mathrm{C}$ for $3-4$ hrs until reaching $\sim 4.6 \mathrm{pH}$. All the cultured milk groups were then left for a final fermentation at $43 \pm 1^{\circ} \mathrm{C}$. The fermentation was terminated when the acidity level reached a $\mathrm{pH}$ value of 4.7. Next yogurt samples were cooled to $5^{\circ} \mathrm{C}$ and held at this temperature for one day. All the experimental samples were subjected to organoleptic, physiochemical, and textural properties as well as $B$. bifidum viability analysis during the 14 day of storage period.

\section{Physicochemical properties}

Total solid content, fat content, $\mathrm{pH}$ and titratable acidity of raw cow's milk were measured according to AOAC [13]. Moisture, crude protein, rude fat, crude fiber, ash and carbohydrate contents of the rice were analyzed according to AOAC [14]. The titratable acidity and $\mathrm{pH}$ of yogurt samples were also measured during the storage period. Water holding capacity (WHC) of red yeast rice flour yogurt was determined according to the method of AOAC [14], Isanga and Zhang [15] with slight modifications. Ten grams of yogurt was measured into an oven dried centrifuge tube and centrifuged at $4600 \mathrm{rpm}$ for $30 \mathrm{~min}$ and the WHC was calculated as follows:

$$
\begin{aligned}
& \text { WHC }(\%)=\left(1-\mathrm{W}_{1} / \mathrm{W}_{2}\right) \times 100 \\
& \text { Where, } \\
& \mathrm{W}_{1}=\text { Weight of whey after centrifugation. } \\
& \mathrm{W}_{2}=\text { Initial weight of yogurt sample. }
\end{aligned}
$$

Apparent viscosity of red yeast rice flour yogurts was measured directly with Brookfield Digital Rheometer, model HA-DVIII ultra (Brookfield Engineering Laboratories INC). The concentrate was placed in a small sample adapter; HA-07 spindle was selected for the sample measurement. A thermostatic water bath provided with the instrument Machine (TMSPro) Food Technology Corporation, Sterling, Virginia, USA) was used to regulate the sample temperature. The rheological parameters and texture hardness for red yeast rice flour yogurts were measured.

\section{Textural Properties}

Texture profile analysis of plain and RYRF yoghurt samples (which shape was $2 \times 2 \times 2$ cylindrical) was done using a Universal Testing apparatus equipped with $1000 \mathrm{~N}$ (250 lbf) load cell and connected to a computer programmed with Texture Pro $^{\mathrm{TM}}$ texture analysis software (program, DEV TPA with 2sec holding time between cycles). A flat rod probe ( $49.95 \mathrm{~mm}$ in diameter) to uniaxial compressed samples with the following parameters conduction to $30 \%$ of their original height. Each sample was subjected to two subsequent cycles (bites) of compressiondecompression. Data were collected and the texture profile parameters were calculated from DEV TPA texture analyzer and computer interface. Calculation described by Bourne [16] Szczesniak et al. [17] was used to obtain the texture profile parameters which included (hardness, cohesiveness, springiness, gumminess and chewiness).

\section{Sensory properties}

Stored RYRF yoghurt samples were assessed by 8 panelists using a sensory rating scale of 1 (poor) to 9 (excellent) for some sensory parameters such as the color, odor, texture, flavor, and overall acceptability, as described by Bodyfelt et al. [18]. All RYFR yogurt samples were presented to the panelists in the plastic jars $(80 \mathrm{ml})$ and at $4^{\circ} \mathrm{C}$ to $6^{\circ} \mathrm{C}$. The tasting panel was randomly selected among the staff members who very familiar with fermented dairy products and who were evaluated for sensory acuity and consistency.

\section{Statistical analysis}

The data from the organoleptic, physicochemical and textural properties and B. bifidum viability were analyzed using by one-way ANOVA using SPSS.16 statistical software. A p value $<0.05$ was considered statistically significant for all analysis.

\section{Results and Discussion}

The chemical composition of the rice for moisture, crude protein, crude fat, crude fiber, ash and carbohydrate were $11.00 \pm 0.019 \%, 20.00$ $\pm 0.02 \%, 0.80 \pm 0.01 \%, 0.20 \pm 0.03 \%, 0.60 \pm 0.02 \%$ and $74.40 \pm 0.01 \%$, respectively.

\section{Organoleptic properties of RYRF yoghurts}

The effect of different RYRF on the organoleptic properties of yoghurt is given in Table 1. Significant differences were observed among all the sensory attributes of yoghurt $(p<0.05)$ (Table 1$)$. The $3 \%$ RYRF yoghurts had highest color, texture, flavor, odor and overall acceptability score in comparison to $1 \%$ and $2 \%$ RYRF yoghurts. The scores of color, texture, flavor, odor and overall acceptability were significantly $(p>0.05)$ changed by the increase of RYRF concentration and the prolong storage time in 2 weeks at $5^{\circ} \mathrm{C}$. However, all the organoleptic properties slightly decreased during the storage of RYRF yoghurts. The decline in organoleptic properties during storage might be related to the associated decrease in $\mathrm{pH}$ values [19-21].

\section{Physicochemical characteristics of the red yoghurts}

pH values and titratable acidity: The $\mathrm{pH}$ values and titratable acidity of the RYRF yoghurts were detected during storage for 14 days at $5^{\circ} \mathrm{C}$. The results revealed that $\mathrm{pH}$ values of control, $1 \%, 2 \%$ and $3 \%$ of RYRF yoghurts significantly decreased $(p<0.05)$, while the titratable acidity significantly increased $(p<0.05)$ during the storage (Figure 1). The Decline of $\mathrm{pH}$ values and simultaneous increase in titratable acidity of the plain and RYRF yoghurts could be attributed to the starter culture's activity, such as post acidification by bacteria used during fermentation and storage period [22-24]. The fiber in rice might have improved the growth and activity of lactic acid bacteria in the 
Citation: Darwish AZ, Darwish SM, Ismail MA (2017) Utilization of Fermented Yeast Rice by the Fungus Monascus ruber AUMC 4066 as Food Coloring Agents. J Food Process Technol 8: 645. doi: 10.4172/2157-7110.1000645

Page 3 of 6

\begin{tabular}{|c|c|c|c|c|c|c|}
\hline Concentration (RYRF) & Storage date (day) & Color & Texture & Flavor & Odor & Over all acceptability \\
\hline \multirow{3}{*}{$1 \%$} & 1 & $6.93 \pm 0.49^{a}$ & $7.62 \pm 0.58^{\mathrm{a}}$ & $8.12 \pm 0.58^{a}$ & $7.68 \pm 0.37^{a}$ & $7.31 \pm 0.59^{a}$ \\
\hline & 7 & $6.68 \pm 0.59^{a b}$ & $7.27 \pm 0.66^{\mathrm{ab}}$ & $7.68 \pm 0.45^{\mathrm{ab}}$ & $6.68 \pm 0.59^{b}$ & $6.87 \pm 0.51^{\mathrm{ab}}$ \\
\hline & 14 & $5.31 \pm 0.65^{b}$ & $5.37 \pm 1.02^{\mathrm{b}}$ & $6.01 \pm 0.66^{a}$ & $5.37 \pm 0.83^{c}$ & $5.12 \pm 0.35^{b}$ \\
\hline \multirow{3}{*}{$2 \%$} & 1 & $8.25 \pm 0.37^{a}$ & $8.25 \pm 0.75^{\mathrm{a}}$ & $8.64 \pm 0.26^{a}$ & $8.68 \pm 0.37^{a}$ & $8.56 \pm 0.41^{\mathrm{a}}$ \\
\hline & 7 & $7.81 \pm 0.25^{b}$ & $7.93 \pm 0.03^{b}$ & $8.12 \pm 0.59^{b}$ & $7.93 \pm 0.49^{b}$ & $7.50 \pm 0.37^{\mathrm{ab}}$ \\
\hline & 14 & $7.31 \pm 0.37^{c}$ & $6.87 \pm 0.51^{c}$ & $7.37 \pm 0.35^{c}$ & $6.12 \pm 0.79^{c}$ & $7.18 \pm 0.59^{b}$ \\
\hline \multirow{3}{*}{$3 \%$} & 1 & $9.25 \pm 0.59^{\mathrm{a}}$ & $9.25 \pm 0.75^{\mathrm{a}}$ & $9.75 \pm 0.26^{\mathrm{a}}$ & $8.68 \pm 0.37^{a}$ & $9.56 \pm 0.41^{\mathrm{ab}}$ \\
\hline & 7 & $8.62 \pm 0.35^{\mathrm{b}}$ & $8.68 \pm 0.37^{b}$ & $8.68 \pm 0.59^{b}$ & $7.93 \pm 0.49^{b}$ & $8.43 \pm 0.41^{\mathrm{ab}}$ \\
\hline & 14 & $7.50 \pm 0.37^{c}$ & $7.50 \pm 0.53^{c}$ & $7.37 \pm 0.35^{c}$ & $6.12 \pm 0.79^{c}$ & $7.50 \pm 0.59^{b}$ \\
\hline
\end{tabular}

$a, b, c$ Values in the same columns having different superscripts are significantly different $(p<0.05)$.

Table 1: Organoleptic properties of RYRF yoghurts samples during 14 day at $5^{\circ} \mathrm{C}$ (mean \pm standard deviation)
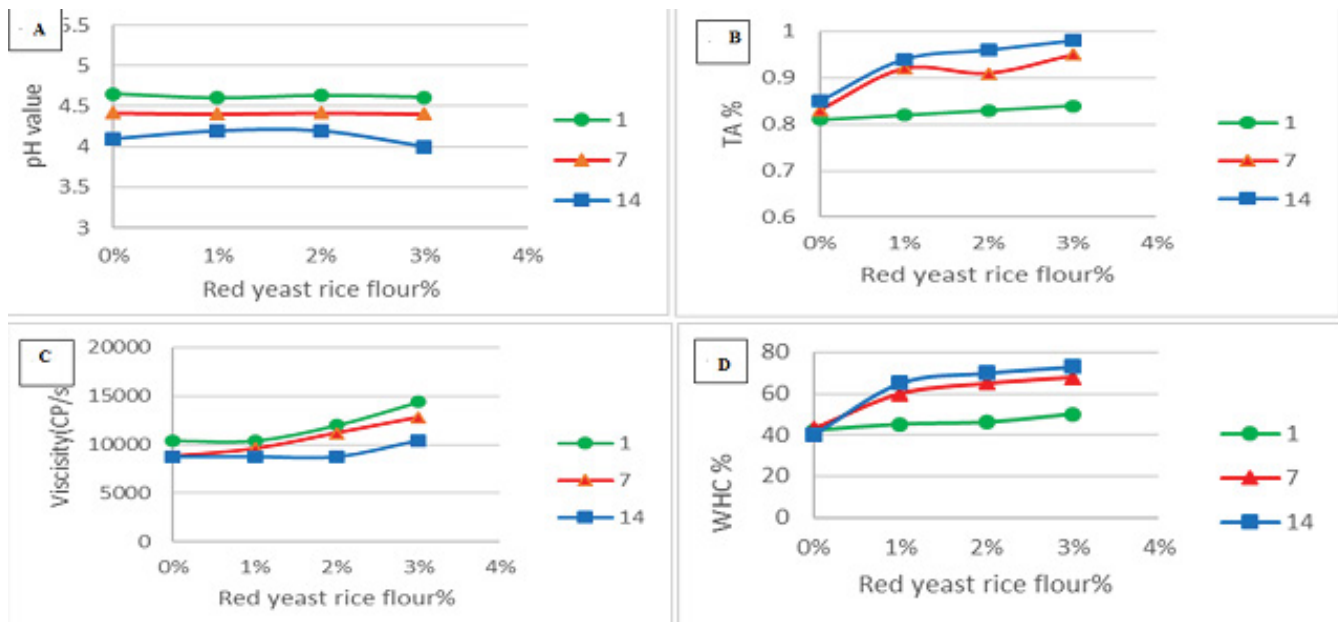

Figure 1: The changes of $\mathrm{A}$ : mean $\mathrm{pH}$ values and $\mathrm{B}$ : mean values of titratable acidity, C: mean apparent viscosity and mean, $\mathrm{D}$ : Water holding capacity (WHC) of the RYRF yoghurts at control $1 \%, 2 \%$ and $3 \%$ at during 14 days at $5^{\circ} \mathrm{C}$ respectively.

\begin{tabular}{|c|c|c|c|c|c|c|c|}
\hline $\begin{array}{c}\text { Concentration } \\
\text { (RYRF) }\end{array}$ & Storage days & Hardness & Adhesiveness & Cohesivess & Springiness & Gumminess & Chewiness \\
\hline \multirow{3}{*}{ Control 0\% } & 1 & $0.7 \pm 0.10^{\mathrm{a}}$ & $0.176 \pm 0.02^{a}$ & $0.25 \pm 0.01^{a}$ & $13.69 \pm 2.32^{\mathrm{a}}$ & $0.20 \pm 0.12^{\mathrm{a}}$ & $3.05 \pm 1.52^{\mathrm{a}}$ \\
\hline & 7 & $0.6 \pm 0.20^{\mathrm{b}}$ & $0.175 \pm 0.01^{\mathrm{ab}}$ & $0.67 \pm 0.05^{b}$ & $13.75 \pm 1.61^{b}$ & $0.30 \pm 0.24^{b}$ & $4.45 \pm 1.00^{b}$ \\
\hline & 14 & $0.9 \pm 0.20^{c}$ & $0.203 \pm 0.03^{b}$ & $0.39 \pm 0.03^{c}$ & $13.75 \pm 1.25^{b}$ & $0.40 \pm 0.12^{c}$ & $5.80 \pm 2.00^{c}$ \\
\hline \multirow{3}{*}{$1 \%$} & 1 & $0.7 \pm 0.10^{\mathrm{a}}$ & $0.244 \pm 0.04^{a}$ & $0.28 \pm 0.03^{a}$ & $13.65 \pm 2.23^{a}$ & $0.25 \pm 0.15^{\mathrm{a}}$ & $3.15 \pm 3.11^{a}$ \\
\hline & 7 & $0.9 \pm 3.43^{b}$ & $0.228 \pm 0.04^{b}$ & $0.45 \pm 0.01^{b}$ & $13.75 \pm 1.65^{b}$ & $0.40 \pm 0.34^{b}$ & $5.57 \pm 1.85^{b}$ \\
\hline & 14 & $1.0 \pm 0.10^{c}$ & $0.294 \pm 0.03^{c}$ & $0.49 \pm 0.12^{c}$ & $13.75 \pm 3.03^{b}$ & $0.50 \pm 0.10^{c}$ & $6.99 \pm 1.71^{c}$ \\
\hline \multirow{3}{*}{$2 \%$} & 1 & $0.8 \pm 0.20^{\mathrm{a}}$ & $0.259 \pm 0.02^{a}$ & $0.34 \pm 0.03^{a}$ & $13.55 \pm 1.05^{a}$ & $0.25 \pm 0.21^{a}$ & $3.48 \pm 2.13^{a}$ \\
\hline & 7 & $0.9 \pm 0.02^{\mathrm{b}}$ & $0.258 \pm 0.03^{\mathrm{ab}}$ & $0.54 \pm 0.05^{b}$ & $13.72 \pm 1.13^{b}$ & $0.50 \pm 0.34^{b}$ & $6.57 \pm 1.52^{b}$ \\
\hline & 14 & $1.0 \pm 0.30^{c}$ & $0.294 \pm 0.03^{b}$ & $0.47 \pm 0.02^{c}$ & $13.75 \pm 2.15^{c}$ & $0.50 \pm 0.23^{b}$ & $6.71 \pm 1.43^{c}$ \\
\hline \multirow{3}{*}{$3 \%$} & 1 & $0.9 \pm 0.30^{\mathrm{a}}$ & $0.342 \pm 0.06^{a}$ & $0.39 \pm 0.06^{\mathrm{a}}$ & $13.52 \pm 1.12^{\mathrm{a}}$ & $0.35 \pm 0.11^{\mathrm{a}}$ & $4.70 \pm 2.34^{a}$ \\
\hline & 7 & $1.0 \pm 0.30^{b}$ & $0.486 \pm 0.01^{b}$ & $0.63 \pm 0.01^{b}$ & $13.75 \pm 3.54^{b}$ & $0.50 \pm 0.17^{b}$ & $6.00 \pm 2.15^{b}$ \\
\hline & 14 & $1.0 \pm 0.20^{\mathrm{ab}}$ & $0.350 \pm 0.03^{a}$ & $0.48 \pm 0.03_{c}$ & $13.75 \pm 1.05^{b}$ & $0.70 \pm 0.22^{c}$ & $9.88 \pm 2.45^{c}$ \\
\hline
\end{tabular}

Table 2: Apparent viscosity of plain and RYRF yoghurts samples during 14 day at $5^{\circ} \mathrm{C}$ (mean \pm standard deviation).

RYRF yoghurts (as prebiotic) that may also explain the higher titratable acidity values for RYRF yogurts compared to plain yogurt throughout the storage [25] (Tables 2 and 3).

Viscosity: The rheological analysis showed that the yoghurt with RYRF had a higher viscosity than control samples. The changes of the viscosity values of the RYRF yoghurts during 14 days' storage at $5^{\circ} \mathrm{C}$ are presented in Figure 1. The viscosity apparently decreased $(p<0.05)$ at the storage prolonged of the RYRF yoghurts. Similar finding was obtained by Cueva and Aryana [26]. Yoghurt viscosity is due to casein-particle aggregation leading to gelation [27]. When $\mathrm{pH}$ values decreased, the mesh of $j$ casein micelle of the milk would become larger, the decreased viscosity is probably because of less water being held by the casein micelle in yoghurts [26] (Table 3).

Water holding capacity (WHC): Higher acidity stimulates separation whey from yoghurt [28]. In the present study addition of RYRF to yoghurt resulted in higher acidity, less whey separation or higher WHC in RYRF yoghurt compared to plain yogurt was observed during the storage period. This may be probably due to high total solids [28] from yoghurts amended RYRF and case strengthened in the RYRF yogurt gel structure and less loose whey. Also rice components 
Citation: Darwish AZ, Darwish SM, Ismail MA (2017) Utilization of Fermented Yeast Rice by the Fungus Monascus ruber AUMC 4066 as Food Coloring Agents. J Food Process Technol 8: 645. doi: 10.4172/2157-7110.1000645

Page 4 of 6

\begin{tabular}{|c|c|c|c|c|c|}
\hline & \multirow{2}{*}{ Storage days } & \multicolumn{4}{|c|}{ RYRF Concentration \% } \\
\hline & & Control & $1 \%$ & $2 \%$ & $3 \%$ \\
\hline \multirow{3}{*}{$\mathrm{pH}$} & 1 & $4.65 \pm 0.0^{\mathrm{a}}$ & $4.60 \pm 0.04^{a}$ & $4.63 \pm 0.01^{\mathrm{a}}$ & $4.4 .61 \pm 0.04 \mathrm{a}$ \\
\hline & 7 & $4.42 \pm 0.01^{b}$ & $4.40 \pm 0.02^{b}$ & $4.42 \pm 0.02^{b}$ & $4.40 \pm 0.03^{b}$ \\
\hline & 14 & $4.10 \pm 0.02^{c}$ & $4.20 \pm 0.02^{c}$ & $4.20 \pm 0.03^{c}$ & $4.00 \pm 0.03^{c}$ \\
\hline \multirow{3}{*}{ TA\% } & 1 & $0.81 \pm 0.24^{\mathrm{a}}$ & $0.82 \pm 0.28^{a}$ & $0.83 \pm 0.12^{\mathrm{a}}$ & $0.84 \pm 0.25^{a}$ \\
\hline & 7 & $0.83 \pm 0.19^{b}$ & $0.92 \pm 0.15^{\mathrm{b}}$ & $0.91 \pm 0.23^{b}$ & $0.95 \pm 0.34^{b}$ \\
\hline & 14 & $0.85 \pm 0.21^{c}$ & $0.94 \pm 0.22^{c}$ & $0.96 \pm 0.27^{c}$ & $0.98 \pm 0.16^{c}$ \\
\hline \multirow{3}{*}{ viscosity } & 1 & $10400 \pm 6.13^{a}$ & $10400 \pm 5.24^{a}$ & $12000 \pm 5.32^{\mathrm{a}}$ & $14400 \pm 6.24^{a}$ \\
\hline & 7 & $8800 \pm 6.14^{b}$ & $9600 \pm 7.42^{b}$ & $11200 \pm 6.28^{b}$ & $12800 \pm 5.98^{b}$ \\
\hline & 14 & $8800 \pm 7.25^{b}$ & $8800 \pm 4.78^{c}$ & $8800 \pm 4.13^{\circ}$ & $10400 \pm 4.59^{\circ}$ \\
\hline \multirow{3}{*}{ WHC\% } & 1 & $42 \pm 0.02^{\mathrm{a}}$ & $45 \pm 0.02^{a}$ & $46 \pm 0.03^{a}$ & $50 \pm 0.04^{a}$ \\
\hline & 7 & $43 \pm 0.01^{b}$ & $60 \pm 0.05^{b}$ & $65 \pm 0.01^{b}$ & $68 \pm 0.04^{b}$ \\
\hline & 14 & $40 \pm 0.01^{\circ}$ & $65 \pm 0.01^{\circ}$ & $70 \pm 0.02^{c}$ & $73 \pm 0.02^{c}$ \\
\hline
\end{tabular}

Table 3: The mean changes of the $\mathrm{pH}$, titratable acidity $\%(\mathrm{TA})$, viscosity $(\mathrm{CP} / \mathrm{s})$ and $\mathrm{WHC} \%$ of plan and $\mathrm{RYRF}$ yoghurts samples during 14 day at $5^{\circ} \mathrm{C}$ (mean \pm standard deviation).
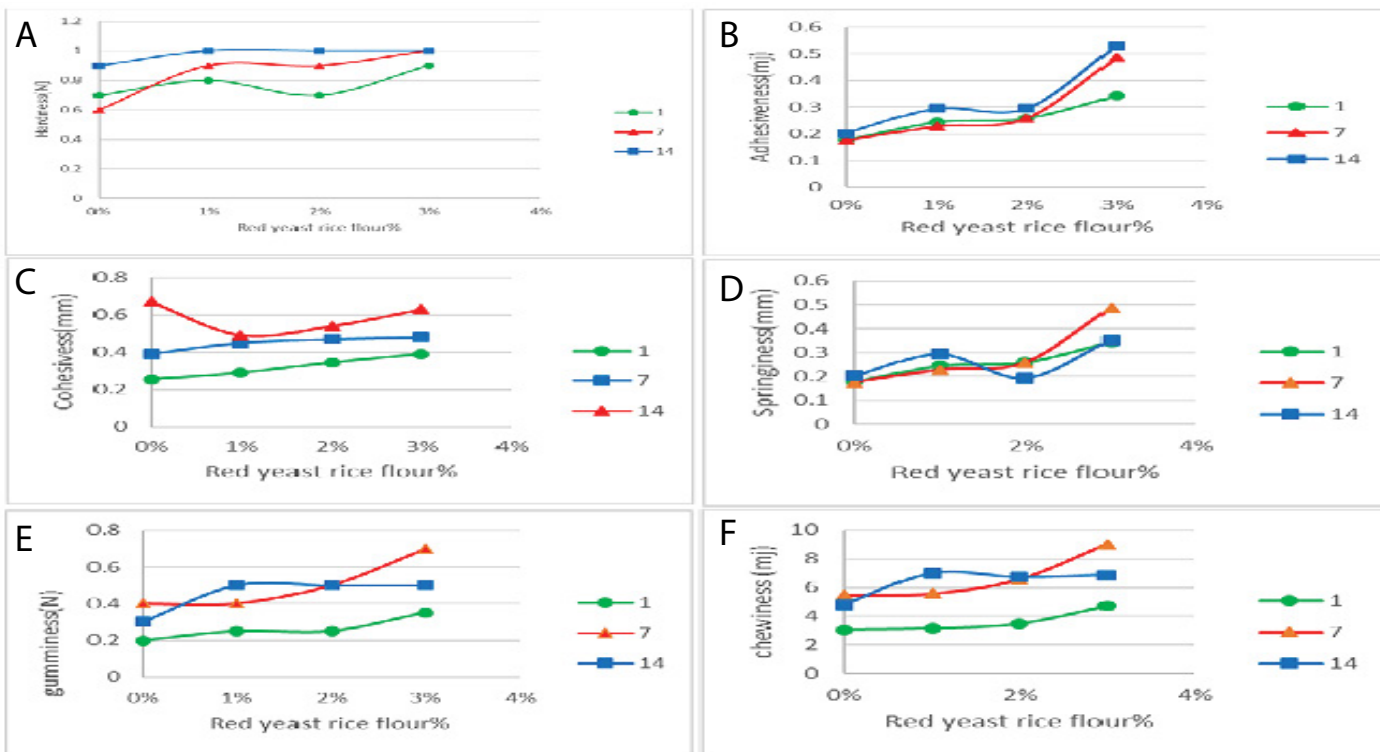

Figure 2: The changes of mean values of $A$ : hardness, B: adhesiveness, C: cohesivess, D: springiness, E: gumminess and F: chewiness and of the RYRF yoghurts at control, $1 \%, 2 \%, 3 \%$ at during 14 days at $5^{\circ} \mathrm{C}$

can enhance the texture, gelling, thickening and stabilizing food properties products [29]. The current results are also in agreement with the previous studies on inulin, orange, apple and wheat fibres [29-32]. Increase in WHC as the storage time progresses could also be due to reabsorption of whey back into the yogurt gel [33]. In contrast, Küçükçetin et al. [34] reported a decreasing trend in WHC of plain yogurt during 15 days of storage at $4^{\circ} \mathrm{C}$.

\section{Textural properties}

Textural properties of RYRF yogurts have been defined by hardness, adhesiveness, cohesiveness, springiness, gumminess and chewiness [35]. The textural properties of RYRF yogurts were also analyzed during 14 days at $5^{\circ} \mathrm{C}$ and the results revealed significant differences $(p<0.05)$ throughout the shelflife period, being not similar at 1 and 14 days for each type of RYRF yogurt. The texture profile differed with RYRF percentage and storage period. Hardness and adhesiveness has increased with the addition of $1 \%, 2 \%$ and $3 \%$ RYRF to yoghurt during the storage period. These results agree with those obtained by the previous works who reported an increase in hardness and adhesiveness of yogurts obtained with the $2 \%$ oatmaltodextrin during refrigerated storage for 21 days [36,37], and those obtained by Kasenkas [38] during storage of probiotic torba yogurt. The adhesiveness had a positive effect on the thickness of the yogurts, and was an important factor governing the stability of the products resulting in good mouth-feel and improving the texture characteristics and the stability of yogurts during storage [38]. The RYRF yogurts significantly $(p<0.05)$ increased the cohesiveness and springiness of the yogurts during storage period (Figure 2). Cohesiveness and springiness are related to stronger gel structures, indicating greater structural integrity; may be due to the increase in charged groups on the amino acid groups-a function of whey protein denaturation [38]. Chewiness and gumminess were found to be affected positively by RYRF content in yoghurt samples.

\section{Bifidobacterium bifidum viability}

Live probiotics in yogurts confer health benefits to the host when 
Citation: Darwish AZ, Darwish SM, Ismail MA (2017) Utilization of Fermented Yeast Rice by the Fungus Monascus ruber AUMC 4066 as Food Coloring Agents. J Food Process Technol 8: 645. doi: 10.4172/2157-7110.1000645

\begin{tabular}{|c|c|c|c|c|}
\hline \multirow{2}{*}{ Storage days } & \multicolumn{4}{|c|}{ RYRF Concentration } \\
\cline { 2 - 5 } & control & $\mathbf{1 \%}$ & $\mathbf{2 \%}$ & $\mathbf{3 \%}$ \\
\hline 1 & $8.1 \pm 0.52^{\mathrm{a}}$ & $8.2 \pm 0.45^{\mathrm{a}}$ & $8.2 \pm 0.53^{\mathrm{a}}$ & $8.3 \pm 0.62^{\mathrm{a}}$ \\
\hline 7 & $7.9 \pm 0.52^{\mathrm{b}}$ & $8.9 \pm 0.63^{\mathrm{b}}$ & $8.8 \pm 0.50^{\mathrm{b}}$ & $9.0 \pm 0.56^{\mathrm{b}}$ \\
\hline 14 & $6.1 \pm 0.32^{\mathrm{c}}$ & $7.0 \pm 0.50^{\mathrm{c}}$ & $7.3 \pm 0.46^{\mathrm{c}}$ & $7.0 \pm 0.49^{\mathrm{c}}$ \\
\hline
\end{tabular}

$a, b, c$ Values in the same columns having different superscripts are significantly different $(p<0.05)$.

Table 4: Viability of Bifidobacterium bifidum $\left(\log \mathrm{CFU} / \mathrm{g}^{-1}\right)$ of plain and RYRF yoghurts samples during 14 day at $5^{\circ} \mathrm{C}$ (mean \pm standard deviation).

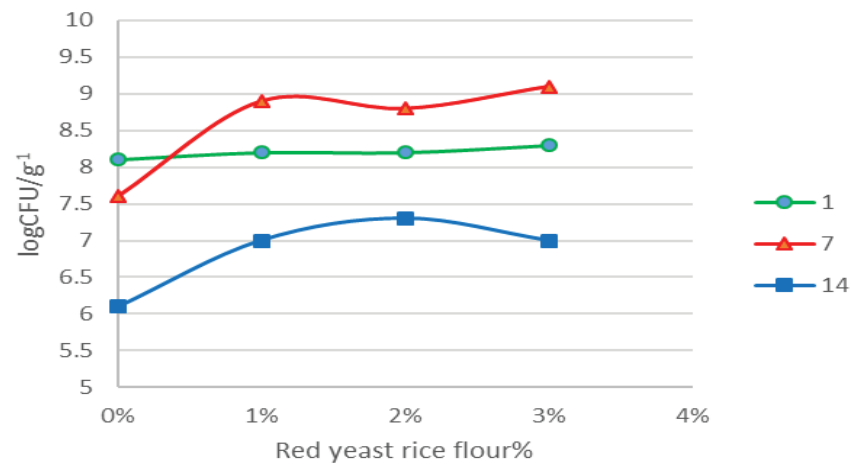

Figure 3: Viability of Bifidobacterium bifidum in RYRF at control, $1 \%, 2 \%, 3 \%$ at during 14 days at $5^{\circ} \mathrm{C}$.

they are consumed in appropriate quantity. Accepted concentration of probiotic cultures 6-7 log cfu. $\mathrm{g}^{-1}$ of product at the time of consumption. The numbers of B. bifidum in bio-yoghurts were found to be (6-9 log $\left.\mathrm{cfu} / \mathrm{g}^{-1}\right)$ in studied samples which lies in the standards regulated by FAO/WHO $[39,40]$ protocols, but usually not below $6 \log \mathrm{cfu} / \mathrm{g}^{-1}$ (Table 4). Which makes bio-yoghurts to sustain their functional properties for entire time during refrigerated storage. Higher viable numbers of B. bifidum was observed in RYRF yogurt than in plain yogurt (Figure 3). Bifidobacterium spp. are known to produce exopolysaccharides [41]. Thus, exopolysaccharides production by B. bifidum might have been high in RYRF than in plain yogurts. This hypothesis is further supported by the higher survivability of bifidobacteria in RYRF yogurts compared to plain yogurt in the present study.

\section{Conclusion}

Supplementation of the RYRF to the yogurt enhanced physicochemical properties, textural properties, B. bifidum viability of yoghurt during storage for 14 days at $5^{\circ} \mathrm{C}$. All concentration added RYRF to yoghurts showed higher titratable acidity, viscosity, WHC, hardness, adhesiveness and cohesivess compared to that of plain yogurts throughout the storage period. The numbers of B. bifidum in RYRF yoghurts (6-9 $\left.\log \mathrm{cfu} . \mathrm{g}^{-1}\right)$ agreed with those standards and regulations of the previous studies but usually not below $10^{6} \mathrm{cfu} / \mathrm{g}$ so RYRF yoghurts sustained their functional properties for entire time during storage. Addition of RYRF to yoghurt also exhibited stimulatory effect on the B. bifidum growth. In the case of RYRF the addition of prebiotics $B$. bifidum caused an increase in $t$ viscosity and hardness values indicating viability of the process to obtain a commercial product.

\section{References}

1. Michael M, Phebus RK, Schmidt KA (2010) Impact of a plant extract on the viability of Lactobacillus delbrueckii ssp. bulgaricus and Streptococcus thermophilus in nonfat yogurt. Int Dairy J 20: 665-672.

2. Wong HC, Koeheler PE (1983) Production of red water soluble Monascus pigments. J Food Sci 48: 1200- 1203.
3. Babitha S, Carvalho JC, Soccol CR, Pandey A (2008) Effect of light on growth pigment production and culture morphology of Monascus purpureus in solidstate fermentation. World J Microbiol Biotechnol 24: 2671-2675.

4. Hajjaj H, Blanc P, Groussac E, Goma G, Uribelarrea J, et al. (1999) Improvement of red pigment/citrinin production ratio as a function of environment conditions by Monascus ruber. Biotechnol Bioeng 64: 497-501.

5. Hong MY, Seeram NP, Zhang Y, ChinY, Heber D (2008) Anti-cancer effects of Chinese red yeast rice beyond monacolin $\mathrm{K}$ alone in colon cancer cells. J Nutr Biochem 19: 448-458.

6. Wong HC, Lin YC, Koehler PE (1981) Regulation of growth and pigmentation of Monascus purpureus by carbon and nitrogen concentrations. Mycologia 3 649-654.

7. Arunachalam C, Narmadhapriya D (2011) Monascus fermented rice and its beneficial aspects: a new review. Asia J Pharma Clinic Res 4: 29-31.

8. Mostafa EM, Abbady MS (2014) Secondary metabolites and bioactivity of the Monascus pigments review article. Global J Biotech Biochem 9: 01-13.

9. Wang JZ, Lu J, Chi W, Wang M, Su P, et al. (1997) Multicenter clinical trial of the serum lipid-lowering effects of a Monascus purpureus (red yeast) rice preparation from traditional Chinese medicine. Current Therapeutic Res 58 964-978.

10. Chen YP, Tseng CP, Chien IL, Wang WY, Liaw LL, et al. (2008) Exploring the distribution of citrinin biosynthesis related genes among Monascus species. J Agric Food Chem 56: 11767-11772.

11. Moharram AM, Mostafa EM, Ismail MA (2012) Chemical profile of monascus ruber strains. Food Technol Biotechnol 50490-499:

12. Tamime AY, Robinson RK (2007) Yoghurt: Science and technology (3rdedn). Woodhead Publishing Limited and CRCPress, LLC, Boca Raton, FL.

13. AOAC (2000) Association of Official Analytical Chemists. Official Methods of Analysis Association of Official Agriculture Chemists, Georgea Banta Co. Inc Wisconsin:

14. AOAC (2005) Official Methods of Analysis. Association of Official Analytical Chemists, Gaithursburg, MD, USA.

15. Isanga J, Zhang G (2009) Production and evaluation of some physicochemical parameters of peanut milk yogurt. LWT-Food Sci Technol 42: 1132-1138.

16. Bourne M (1978) Texture profile analysis. Food Tech 32: 62-66.

17. Szczesniak A, Brandt M, Freidman H (1963) Development of standard rating scales for mechanical parameters and correlation between the objective and sensory texture measurements. Food Tech 22397-403: .

18. Bodyfelt FW, Tobias J, Trout GM (1988) The sensory evaluation of dairy products. Van Nostrand Reinhold, New York.

19. Chen S, Lv B, Du X, Chen F (2012) Pigment from red fermented rice as colouring agent for stirred skimmed milk yoghurts. Int J Dairy Technol 65 287-292.

20. Ott A, Hugi A, Baumgartner M, Chaintreau A (2000) Sensory investigation of yogurt flavor perception: mutual influence of volatiles and acidity. J Agri Food Chem 48: 441-450.

21. Rohm H, Kovac A, Kneifel W (1994) Effects of starter cultures on sensory properties of set-style yoghurts determined by quantitative descriptive analysis. J Sensory Studie 9: 171-186.

22. Ranadheera CS, Evans CA, Adams MC, Baines SK (2012) Probiotic viability and physico-chemical and sensory properties of plain and stirred fruit yogurts made from goat's milk. Food Chem 135: 1411-1418.

23. Tamime YA, Robinson RK (1999) Yoghurt: Science and technology (2ndedn). Woodhead Publishing Ltd, Cambridge, UK.

24. Vahedi N, Tehrani MM, Shahidi F (2008) Optimizing of fruit yogurt formulation and evaluating its quality during storage. American-Eurasia J Agri Environ Sci 3: $922-927$.

25. Sendra E, Fayos P, Lario Y, Fernández-López J, Sayas-Barberá E, et al. (2008) Incorporation of citrus fibers in fermented milk containing probiotic bacteria. Food Microbiol 25: 13-21.

26. Cueva O, Aryana KJ (2008) Quality attributes of a heart healthy yogurt. LWTFood Science and Technology 41: 537-544. 
Citation: Darwish AZ, Darwish SM, Ismail MA (2017) Utilization of Fermented Yeast Rice by the Fungus Monascus ruber AUMC 4066 as Food Coloring Agents. J Food Process Technol 8: 645. doi: 10.4172/2157-7110.1000645

27. Damian C Oroian MA, Leahu A, Carpiuc N (2012) Effect of addition of carrageenan in rheological behaviour of yogurt. Food Environ Safe J Faculty Food Eng 2: 53-58.

28. Remeuf F, Mohammed S, Sodini I, Tissier JP (2003) Preliminary observations on the effects of milk fortification and heating on microstructure and physical properties of stirred yogurt. Int Dairy J 13: 773-782.

29. Abdul-Hamid A, Luan YS (2000) Functional properties of dietary fibre prepared from defatted rice bran. Food Chem 68: 15-19.

30. Guggisberg D, Cuthbert-Steven J, Piccinali P, Beutikofer U, Eberhard P (2009) Rheological, microstructural and sensory characterization of low-fat and whole milk set yoghurt as influenced by inulin addition. Int Dairy J 19: 107-115.

31. Kip P, Meyer D, Jellema RH (2006) Inulins improve sensoricand textura properties of low-fat yoghurts. Int Dairy J 16: 1098-1103.

32. Zomorodi S, Aberoon N, Khosrowshahi Asli A (2015) Increase the survival of Lactobacillus acidophilus and improved quality properties of senbiotic yoghurt using apple and wheat fibers. Iran J Food Sci Technol 48: 203-214.

33. Casarotti SN, Monteiro DA, Moretti M, Penna ALB (2014) Influence of the combination of probiotic cultures during fermentation and storage of fermented milk. Food Res Int 59: 67-75

34. Küçükçetin A, Demir M, Aşci A, Çomak EM (2011) Graininess and roughness of stirred yogurt made with goat's, cow's or a mixture of goat's and cow's milk. Small Ruminant Res 96: 173-177.
35. Domagała J, Sady M, Grega T, Bonczar G (2005) The influence of storage time on rheological and texture of yoghurts with the addition of oat-maltodextrin as the fat substitute. Int J Food Prop 8: 439-448.

36. Zhao QZ, Wang JS, Zhao MM, Jiang YM, Chun C (2006) Effect of casein hydrolysates on yoghurt fermentation and texture properties during storage. Food Technol Biotechnol 44: 429-434.

37. Megenis BR, Prudencio ES, Amboni RDMC, Cerquierra NGJ, Olivierra RVB, et al. (2006) Compositional and physical properties of yogurt manufactured from whey and cheese concentrated by ultrafiltration. Int J Food Sci Technol 41: 560-568.

38. Kasenkas $H$ (2010) Effect of using different probiotic cultures on properties of torba (strained) yoghurt. Mljekarstvo 60: 19-29.

39. FAO/WHO (2002) Guidelines for the evaluation of probiotics in food. Report of a Joint FAO/WHO working group on drafting guidelines for the evaluation of probiotics in food. Ontario, Canada.

40. Mckinley M (2005) The nutrition and health benefits of yogurt. Int J Dairy Technol 58: 1-12.

41. Prasanna PHP, Grandison A, Charalampopoulos D (2014) Bifidobacteria in milk products: An overview of physiological and biochemical properties, exopolysaccharide production, selection criteria of milk products and health benefits. Food Res Int 55: 247-262. 